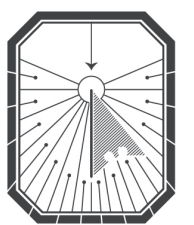

KYIV-MOHYLA

LAW \& POLITICS JOURNAL

KYIV-MOHYLA SCHOLARLY PEER-REVIEWED JOURNALS

Substituting for the State: The Role of Volunteers in Defense Reform in Post-Euromaidan Ukraine

Author(s): Kateryna Zarembo

Source: Kyiv-Mohyla Law and Politics Journal 3 (2017): 47-70

Published by: National University of Kyiv-Mohyla Academy

http://kmlpj.ukma.edu.ua/ 


\title{
Substituting for the State: The Role of Volunteers in Defense Reform in Post-Euromaidan Ukraine
}

\author{
Kateryna Zarembo \\ New Europe Center; \\ National University of Kyiv-Mohyla Academy
}

\begin{abstract}
While the role of volunteers in sustaining the Ukrainian armed forces against the backdrop of Russian aggression since 2014 has been widely acknowledged in literature, the effect of volunteer initiatives on the state defense capacity in longer term has not been studied thus far. This article aims to address this gap and explore whether volunteer participation led to institutional strengthening of the Ukrainian defense state capacity or to its weakening. The analysis will conclude that the volunteers in fact contributed to both — strengthening the state and weakening it at the same time; the outcome dependent on the context in which the volunteers took action at different times. While volunteer participation failed to bring about systemic reform, it did provide powerful democratic oversight over the state's key defense institution.
\end{abstract}

Key Words: civil society, Ukraine, volunteers, institutions, defense reform, Euromaidan.

\section{Introduction}

It has been acknowledged that "the large-scale mobilization of Ukrainian society is ... arguably Euromaidan's and its tragic aftermath's most far-reaching legacy."1 Indeed, the role of volunteers in sustaining the Ukrainian armed forces against the backdrop of Russian aggression cannot be overestimated. In 2014 the Armed Forces of Ukraine lacked troops, capacity and resources both quality- and quantity-wise - according to the Minister of Defense Ihor Teniukh, the number of deployable troops during the Crimea annexation only reached $1,500-2,000,{ }^{2}$ and only $4 \%$ of Ukrainian troops were provided with necessary equipment, including life-saving helmets and bullet-proof jackets. ${ }^{3}$

1 Rosaria Puglisi, A People's Army: Civil Society as a Security Actor in Post-Maidan Ukraine (Rome: Istituto Affari Internazionali, July 2015), 3.

2 "Stenohrama zasidannia RNBO Ukrainy u zviazku z pochatkom rosiiskoi ahresii v Krymu [Transcript of the National Security and Defense Council of Ukraine Meeting in the Aftermath of the Russian Aggression in the Crimea]," Ukrainska Pravda, February 22, 2016, http://www.pravda.com.ua/ articles/2016/o2/22/7099911/.

3 Ministry of Defense of Ukraine, "Pres-reliz 13 chervnia 2014 roku 'Materialno-tekhnichne zabezpechennia viiskovosluzhbovtsiv Zbroinyh Syl Ukrainy' [Press Release of June 13, 2014 'Material 
At this point, a volunteer movement began to emerge from civil society. The stunning statistics provided by pollster GfK Ukraine, widely quoted to illustrate the scale of change, shows that while before the Euromaidan only $14 \%$ of Ukrainians engaged in voluntary activities, this figure rose to $23 \%$ during and after the Euromaidan. ${ }^{4}$ The survey also revealed that $70 \%$ of the volunteer activities were aimed at helping the military. While there are no precise calculations about the number of citizens engaged in volunteer activities (not least due to the fluid nature of participation), some sociological studies offer insight: in 2014 a survey by the Democratic Initiatives Foundation revealed that $32.5 \%$ of Ukrainians donated money to support Ukraine's armed forces in May-September 2014, while 3\% (over 1 million people) personally collected money, food and equipment and supplied them to the frontline. ${ }^{5}$

The assistance that volunteers provided to the Ukrainian armed forces ranged from provision of technical equipment and resources needed at the frontline, medical services and equipment at hospitals, to social, psychological and legal assistance to the troops and their families. Volunteers also assisted internally displaced persons, coordinated searches of missing people, release of prisoners, etc. ${ }^{6}$ Volunteer engagement in the defense of Ukrainian territory was summarized by Rosaria Puglisi:

[c]ivil society has become de facto a security actor - involved first in the provision of hard security, with the establishment of self-defense units during the Maidan demonstrations and of volunteer battalions following the beginning of hostilities in the east; second, in the procurement of military equipment for the troops and the provision of logistical services (like medical or clerical work), even at the frontlines; and third, in the monitoring and the oversight of defense-related issues and military operations in the Donbas. ${ }^{7}$

and Technical Provision of the Military of Ukraine's Armed Forces']," accessed April 20, 2017, http:// www.mil.gov.ua/dlya-zmi/pres-relizi/pres-reliz-13-chervnya-2014-roku.html.

4 GfK, "Volonterskyi rukh v Ukraini [Volunteer Movement in Ukraine]," December 5, 2014, accessed December 20, 2017, https://www.gfk.com/fileadmin/user_upload/dyna_content_import/2015-o9-. press_releases/data/ua/Documents/Presentations/report_vyshlisky.pdf.

5 Democratic Initiatives Foundation, “32.5\% ukraintsiv osobysto perekazaly svoi koshty na rakhunky ukrainskoi armii [32.5\% of Ukrainians personally donated money to the Ukrainian Armed Forces]," October 21, 2014, accessed December 20, 2017, http://dif.org.ua/article/325-ukraintsivosobisto-perekazali-svoi-koshti-na-rakhunki-ukrainskoi-armii-selyani-vidznachilis-vishchoyudobrochinnistyu-anizh-miski-zhiteli.

6 Denys Horielov and Oleksandr Korniievskyi, Volonterskyi rukh: svitovyi dosvid ta ukrainski hromadianski praktyky [Volunteer Movement: Global Experience and Civil Practices in Ukraine] (Kyiv: National Institute of Strategic Studies, 2015), 18, accessed December 20, 2017, http://web.archive.org/ web/2016041500103o/http://www.niss.gov.ua/content/articles/files/volonter-697e4.pdf. 
The engagement of civil society in a de facto substitution for the state in defense of sovereign territory presents a unique case for academic analysis. In the first place, it shows civil society in an unusual role of a hard security provider. Secondly, it reveals the effects of such intervention on the state capacity to perform its ordinary functions. As mentioned, the questions this article therefore aims to answer are the following: What are the effects of volunteer participation on defense sector reform in post-Euromaidan Ukraine? Did it lead to the institutional strengthening of the Ukrainian state's defense capacity or, to its weakening?

The article is divided into the following parts: a literature review of civil society-state relations to date, with a special focus at times of conflict; an outline of the research methodology and an empirical analysis of the effect of the volunteers' efforts on the reform of the Ministry of Defense of Ukraine. The empirical data suggests that volunteer organizations contributed to both strengthening the state's defense capacities and weakening them at the same time, primarily by substitution for the state, which is typical for fragile states. Finally, the article concludes by mapping out the lacunas awaiting further research.

\section{Civil Society-State Relationship in Fragile States}

It is argued that civil society promotes good governmental performance through two primary mechanisms: an "advocacy" or "watchdog" function and "service delivery" or "substitution" for the state. ${ }^{8}$ The "advocacy" model is "by far the most common way in which civil society's contribution to good governance and public goods provision is conceptualized" ${ }^{9}$ and which is also attributed as the key role for civil society in literature on security sector reform, even though the security sector is "one of the most resistant to public input." ${ }^{10}$ However, the "substitution" model should not be overlooked. It can operate complementary to the role of the state, when "the activities of civil society groups serve as substitutes for the state that, due to its weakness or the indifference of its leaders, fails to provide the public good in question." 11 Thus, the "substitution" function of civil society in weak or fragile states is especially important as it provides the citizens with the services which otherwise would not be available - e. g. when "neighborhood watch groups compensate for the absence of police protection by organizing nightly security patrols." ${ }^{12}$

If we accept the Oxfam definition of fragile states as "states that fail, through lack of capacity or lack of will, to provide public goods to their citizens - including safety and security, economic

8 Daniel N. Posner, "Civil Society and the Reconstruction of Failed States," in When States Fail: Causes and Consequences, ed. Robert I. Rotberg (Princeton: Princeton University Press, 2004), 237; Graham K. Brown, Civil Society Building in Post-Conflict Countries (Leuven: Centre for Research on Peace and Development Working Paper 28, 2015), 7 .

9 Posner, Civil Society and the Reconstruction of Failed States, 238.

10 Marina Caparini and Philipp Fluri, "Civil Society Actors in Defense and Security Affairs," in Civil Society and the Security Sector: Concepts and Practices in New Democracies, eds. Marina Caparini, Philipp Fluri, Ferenc Molnar (Berlin: LIT Verlag, 2006), 13.

11 Posner, Civil Society and the Reconstruction of Failed States, 239. 
well-being, and essential social services,"13 then this definition was applicable to Ukraine and its ability to protect its citizens from Russian military aggression in 2014. As a result, substitution for the state was the function that Ukraine's civil society performed in 2014-2015. According to the Organization for Security and Cooperation in Europe (OSCE), "State authorities were seen not to carry out their protection responsibilities in a sufficient manner, resulting in civil society taking over tasks from the State authorities." 14 Mikhail Minakov observed that "independent actors have taken over some of the state's responsibilities in responding to war and political crises."15

The effect of this substitution on the ability of the state to ultimately perform its functions is not clear. On the one hand, one can hypothesize that civil society engagement contributes to state-building by strengthening state capacities. Alternatively, it could leave the state capacity intact (with the state institutions "relying" on civil society to provide the services in question) or even weaken the state by overtaking its monopoly in certain areas.

The juxtaposition of these two main approaches can be found in the literature. If civil society substitutes for the state at times of weakness, then, according to Henrik Marcussen "civil society will assist the state, as some vital, functional gaps in service delivery will be filled, and other shortcomings be substituted for.... Ultimately, the state can profit from this by showing its ability to cope with shortages while retaining power and control." 16 Others, however, would see "successful grassroots developments and the provision of certain services, otherwise associated with state functions, as destabilizing and undermining factors." ${ }^{17}$ Additional argument is that "it could actually make state-building and institutional development more difficult because NGOs absorb skills and human resources that are needed in these fields." ${ }^{18}$ Some Ukrainian observers believe the latter to be the case for Ukraine: while the volunteer movement supported the state

13 Oxfam International, "Civil Society in Fragile and Conflict-Affected States. Oxfam Policy Compendium Note," July 2013, accessed December 20, 2017, https://www.oxfam.org/sites/www. oxfam.org/files/hpn-civil-society-fragile-states-26o713-en.pdf.

14 OSCE, Civil Society and the Crisis in Ukraine, SEC.FR/125/15/Corr.1 (OSCE Thematic Report, 2015$), 6$.

15 Mikhail Minakov, Corrupting Civil Society in Post-Maidan Ukraine? (Carnegie Endowment for International Peace: Carnegie Moscow Centre, 2015), 1; for more observations on substituting the state by civil society in post-Euromaidan Ukraine see also Chris Dunnett, "How Volunteers Created a Second State Inside Ukraine," Hromadske International, January 30, 2015, accessed December 20, 2017, https://medium.com/@Hromadske/how-volunteers-created-a-second-state-inside-ukraineebefb5d82e1c.

16 Goran Hyden, "Civil Society, Social Capital and Development: Dissection of a Complex Discourse," Studies in Comparative International Development 32.1 (1997): 13.

17 Alan Fowler, "The Role of NGOs in Changing State-Society Relations: Perspectives from Eastern and Southern Africa," Development Policy Review 9 (1991): 63. Cited from Danielle Lessard, "International NGOs and Statebuilding. The Case of Haiti, The Phanton State" (Master's Thesis, Lund University, 2010).

18 Ulrich Schneckener, “Bosnien-Herzegovina. Der aufgezwungene Frieden,” in Den Frieden gewinnen. Zur Konsolidierung von Friedensprozessen in Nachkriegsgesellschaften, eds. Mir A. Ferdowsi and Volker Matthies (Bonn: Dietz 2003), 42-69. 
at the times of its weakness, the oversized and overpotent civil society would pose a threat to it, "[creating] critical obstacles for the state's development in the medium-term."19

The case of Ukraine is more nuanced by the context of conflict and the specific nature of substituted functions, i. e. security and defense. Before 2014 civil society engagement in Ukraine's defense sector was rather limited to the "elitist" circle of think-tanks and defense experts, ${ }^{20}$ which performed the watchdog functions over the defense sector. In security sector reform (SSR) jargon this is defined as 'democratic oversight', i. e. public monitoring and scrutiny of the security sector. ${ }^{21}$ However, Russian aggression led to Ukraine's civil society entering the defense sector on a previously unseen scale, with an unusual function. The consequence of civil society mobilization in conflict is that it actually challenges the relevant power structures - by taking over the functions of a state which, according to the Westphalian notion of a state, are supposed to be a state's exclusive monopoly - i. e. provision of security and protection of society. ${ }^{22}$

The goal of this article is to review and assess the effect of civil society engagement in countering Russian aggression since 2014 on the success of the defense sector reform (DSR) in Ukraine. The Geneva Centre for the Democratic Control of Armed Forces (DCAF) definition for DSR as "a coordinated series of actions designed to improve the efficiency and effectiveness of a state's armed forces" is adopted for this article. ${ }^{23}$ Importantly, in this paper the understanding of DSR departs from a traditional notion of DSR as a part of security sector reform (SSR), which tends to place a low emphasis on strengthening the capacity of the armed forces, and instead prioritises the establishment of democratic control over the security sector. ${ }^{24}$ Rather, Ukraine's case and the armed conflict in which it finds itself places it closer to Wright's definition of DSR for Georgia: "For Georgia, a country with a weak military tradition and unresolved domestic conflicts causing political controversy at home, military reform was not just an abstract step toward democracy but a potential means to an end of resolving those same conflicts by force or threat

19 Minakov, Corrupting Civil Society, 1.

20 See, e. g. Leonid Polyakov, "Defence and Security-Focused Think Tanks in Ukraine," in Civil Society and the Security Sector: Concepts and Practices in New Democracies, eds. Marina Caparini, Philipp Fluri, Ferenc Molnar (Berlin: LIT Verlag, 2006).

21 Marina Caparini, Civil Society And Democratic Oversight Of The Security Sector: A Preliminary Investigation (Geneva: The Geneva Centre for the Democratic Control of Armed Forces (DCAF) Working Paper 132, 2004), 22.

22 Catherine Barnes, Agents for Change: Civil Society Roles in Preventing War and Building Peace (The Hague: European Centre for Conflict Prevention, 2006), 7.

23 DCAF, Defense Reform Backgrounder (Geneva: The Geneva Centre for the Democratic Control of Armed Forces (DCAF), 2009).

24 The widely-accepted definition of SSR suggested by the OECD sounds as follows: "Security sector reform is the transformation of the security system which includes all the actors, their roles, responsibilities and actions, so that it is managed and operated in a manner that is more consistent with democratic norms and sound principles of good governance, and thus contributes to a wellfunctioning security framework," OECD, OECD DAC Handbook on Security System Reform: Supporting Security and Justice (Paris: OECD, 2008). 
of force." 25 Thus, for the purposes of this paper, capacity-building and democratic oversight are two sides of the same coin and indispensable parts of DSR: "[h] aving a democratically controlled military or police is only half the task of security sector reform; these organisations should also be proficient at fulfilling their legitimate responsibilities for providing the public goods of external security and public security." 26

Of the three roles outlined by Puglisi: volunteer battalions at the frontline; provision and procurement and democratic oversight, this article specifically addresses provision and procurement, which is a unique function for civil society. This includes to some degree an analysis of the third Puglisi role, performance of a "traditional" function of democratic monitoring and oversight by the volunteers. The first role however, that of volunteer battalions, representing civil society in "uncivil" role, is outside the scope of this article.

\section{Research Methodology}

The research question of this article is methodologically challenging. If we accept the change in state institutions (i. e. the Ministry of Defense as a key security bureaucracy) ${ }^{27}$ as a yardstick for the effects of volunteer participation on defense sector reform, then what specific aspects of those changes in state capacity should be considered? (e. g. perception of corruption, number of procurement contracts, staff rotation, etc.)

The functions performed by the volunteer movement to support the state could provide guidance to this question.The state's incapacity to ensure technical and material provision and procurement was one of the most problematic issues in the beginning of the war: for example, in 2014 the Ministry's clothing allowance budget provided only $20-25 \%$ of what was needed. ${ }^{28}$ However, even under those conditions the problem related not only to a lack of funds, but also to corruption and mismanagement of funds: $20 \%$ of the contracts fell through and 60 million UAH (approx. 7,5 million USD, a sum comparable to the annual donations by large volunteer organizations) was returned to the budget. ${ }^{29}$ The Government Defense Anti-Corruption Index

25 Geoffrey Wright, "Defense Reform and the Caucasus: Challenges of Institutional Reform during Unresolved Conflict," Mediterranean Quarterly 20.3 (2009): 39.

26 Marina Caparini, “The Relevance of Civil Society,” in Security Sector Reform: Potentials and Challenges for Conflict Transformation, eds. Clem McCartney, Martina Fischer and Oliver Wils (Berlin: Berghof Research Center for Constructive Conflict Management 2004), 55.

27 Andrew Cottey, Timothy Edmunds and Anthony Forster, "The Second Generation Problematic: Rethinking Democracy and Civil-Military Problematic," Armed Forces and Society 29.1 (2002): 42.

28 Inna Koval, "Nelli Stelmakh: 'Maizhe dva roky my zhyvemo v umovakh voiennoho chasu, a pratsiuvaty prodovzhuiemo za zakonamy myrnoho' [We have been Living in the Conditions of War Time for Two Years but We are Still Working as it It was Peaceful Times]," Forbes Ukraina, December 2, 2015, accessed December 20, 2017, http://forbes.net.ua/ua/nation/1406762-nelli-stelmah-majzhedva-roki-mi-zhivemo-v-umovah-voennogo-chasu-a-pracyuvati-prodovzhuemo-za-zakonam.

29 Anastasiia Rinhis and Halyna Tytysh, "Virus' v ministerstve oborony ['Virus' in the Ministry of Defense]," Ukrainska Pravda, January 28, 2015, accessed December 20, 2017, http://www.pravda.com. ua/cdn/cd1/2015year/volunteer/index.html. 
2015, released biennially by Transparency International, placed Ukraine's defense sector in B and $\mathrm{D}$ (High risk of corruption), indicating that "Ukraine's highest risk area is Procurement, followed by Operations, Personnel, Finance and Political." 30

Thus, the change in state capacity in military provision and procurement (estimated quantitatively and qualitatively) could be taken as a proxy of volunteers' impact. In this case, if it increased over 2014-2017, it could be interpreted as proof that civil society strengthened the state, supporting it until the state regained its ability to perform its crucial functions. If it decreased or remained the same, this could be interpreted as proof that civil society played a crucial role of substituting the state when it was too weak, but failed to contribute or even prevent the reform. This approach, however, tells only one part of the story, since it fails to definitively attribute specific change(s) to the efforts of the volunteers alone.

Another way of defining the effect of the volunteer movement on DSR would be to trace the evolution of the movement itself. If the movement aimed at helping the armed forces appeared only in 2014 as a specific and urgent response to the state's deficiencies, we could assume that if the state subsequently began to fulfil its duties once again, then the volunteer movement would cease to perform these functions or would revert to other types of volunteer activity. If, however, the volunteer movement would continue to be engaged in substituting for the state over time, then it de facto would take these functions over from the state.

This article will take both of these indicators - change in state procurement capacity and the volunteer movement dynamics - by looking into two case studies.

The first case study provides an overview of the evolution of the largest volunteer organizations in Ukraine that are engaged in provision and procurement for the Armed Forces. These are: "Wings of Phoenix" ("Kryla Feniksa"), "Come Back Alive" ("Povernys Zhyvym"), "The People's Home Front" ("Narodnyi Tyl"), "Army SOS" ("Armiia SOS"), and "The People's Project" ("Narodnyi Proekt"). These volunteer organizations were chosen based on the following criteria:

1) public acknowledgement, i.e. being listed among the most important volunteer organizations by the media, experts and the government; 31

2) 2014 as the starting year of the operation;

3) a working website and transparent financial accountability;

4) no declared affiliations with a political force.

30 Government Defense Anti-Corruption Index, "Ukraine. 2015," accessed April 21, 2017, http:// government.defenceindex.org/countries/ukraine/.

31 Denys Horielov and Oleksandr Korniievskyi, Volonterskyi rukh: svitovyi dosvid ta ukrainski hromadianski praktyky; "Samyie znachimyie volonterskiie initsiativy goda [The Most Significant Volunteer Initaitives of the Year]," The Insider, December 29, 2014, http://www.theinsider.ua/lifestyle/ geroyam-slava-samye-znachimye-volonterskie-initsiativy-goda/; "Bek-ofis armii [Army's Back Office]," Ukrainska Pravda, 31 July 2015, accessed December 20, 2017, http://www.pravda.com.ua/cdn/ cd1/2015year/back_office/index.html. 
TABLE 1. FIVE LARGEST VOLUNTEER ORGANIZATIONS AT A GLANCE

\begin{tabular}{|c|c|c|c|c|c|}
\hline & TEAM & SPHERES OF & $\begin{array}{l}\text { FUND- } \\
\text { RAISING }\end{array}$ & & VOLUME OF \\
\hline NAME & LEADER & ACTIVITY & STRATEGY & WEBSITE & DONATIONS \\
\hline $\begin{array}{l}\text { "Come } \\
\text { Back Alive” } \\
\text { (“Povernys } \\
\text { Zhyvym) }\end{array}$ & $\begin{array}{l}\text { Vitalii } \\
\text { Deineha }\end{array}$ & $\begin{array}{l}\text { Purchase of } \\
\text { equipment, } \\
\text { development } \\
\text { of intelligence } \\
\text { software, } \\
\text { professional } \\
\text { training courses, } \\
\text { technical } \\
\text { repairments }\end{array}$ & $\begin{array}{l}\text { Public } \\
\text { donations }\end{array}$ & $\begin{array}{l}\text { https:// } \\
\text { savelife.in.ua/ } \\
\text { about/ }\end{array}$ & $\begin{array}{l}121349948 \mathrm{UAH}^{32}(\text { as of } \\
\text { November 2O17) })^{33}\end{array}$ \\
\hline $\begin{array}{l}\text { "The } \\
\text { People's } \\
\text { Home Front" } \\
\text { ("Narodnyi } \\
\text { Tyl") }\end{array}$ & $\begin{array}{l}\text { Roman } \\
\text { Sinitsyn, } \\
\text { Heorhii } \\
\text { Tuka }\end{array}$ & $\begin{array}{l}\text { Tactical medicine } \\
\text { and medical } \\
\text { supplies, provision } \\
\text { of armored vehicles, } \\
\text { drones, etc and } \\
\text { repairs, assistance } \\
\text { to families of fallen } \\
\text { soldiers }\end{array}$ & $\begin{array}{l}\text { Public } \\
\text { donations }\end{array}$ & $\begin{array}{l}\text { http://nt.org. } \\
\text { ua/about/ }\end{array}$ & $\begin{array}{l}\text { In the first } 3-4 \text { months } \\
\text { of operation }-\sim 15 \text { o ooo } \\
\text { USD per month. As of } \\
2017-\sim 25 \text { ooo USD per } \\
\text { month }{ }^{34}\end{array}$ \\
\hline $\begin{array}{l}\text { "Army SOS" } \\
\text { ("Armiia } \\
\text { SOS") }\end{array}$ & $\begin{array}{l}\text { Yurii } \\
\text { Kasianov }\end{array}$ & $\begin{array}{l}\text { Drones and } \\
\text { technology } \\
\text { innovations }\end{array}$ & $\begin{array}{l}\text { Public } \\
\text { donations }\end{array}$ & $\begin{array}{l}\text { http:// } \\
\text { armysos.com. } \\
\text { ua/ }\end{array}$ & $\begin{array}{l}24859370 \mathrm{UAH} \text {, as of } 30 \\
\text { June } 2017^{35}\end{array}$ \\
\hline $\begin{array}{l}\text { "The } \\
\text { People's } \\
\text { Project" } \\
\text { ("Narodnyi } \\
\text { Proekt") }\end{array}$ & $\begin{array}{l}\text { David Ar- } \\
\text { akhamia }\end{array}$ & $\begin{array}{l}\text { Military, healthcare } \\
\text { (rehabilitation of } \\
\text { soldiers through } \\
\text { biotechnologies), } \\
\text { social projects }\end{array}$ & $\begin{array}{l}\text { Crowd- } \\
\text { funding } \\
\text { platform, } \\
\text { i. e. donors } \\
\text { can choose } \\
\text { a specific } \\
\text { project he/ } \\
\text { she wants } \\
\text { to support }\end{array}$ & $\begin{array}{l}\text { http://www. } \\
\text { peoplespro- } \\
\text { ject.com/en/ }\end{array}$ & $\begin{array}{l}\text { The website features } \\
\text { dozens of projects, } \\
\text { some of which may } \\
\text { cost as much as } 1 \text { mln } \\
\text { USD (e.g. http://www. } \\
\text { peoplesproject.com/en/ } \\
\text { biotech/\#report), raised } \\
\text { successfully }\end{array}$ \\
\hline
\end{tabular}

32 Unless indicated by the organization itself, no USD equivalent is provided due to the currency rate fluctuations over the studied period. For example, the Ukrainian currency hryvnia underwent triple reduction from April 2014 to February 2015 (in the first half of 20141 USD was equivalent to 12 UAH and in 20161 USD was worth $27 \mathrm{UAH})$.

33 "Come Back Alive," "About," accessed December 8, 2017, https://savelife.in.ua/about/.

34 Author's interview with a team member of “The People's Home Front," April 10, 2017.

35 Author's calculations based on Army SOS public reporting, accessed December 8, 2017, http:// armysos.com.ua/zviti. 


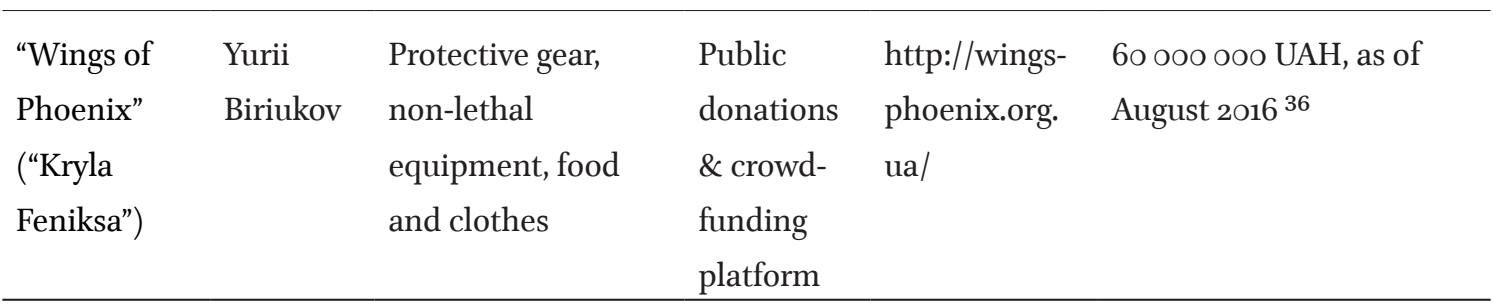

The second case study is a specific reform project at the Ministry of Defense, the socalled "Volunteer Force" which started in 2014. The project consisted of engaging civilians with volunteering experience in the work of the Ministry of Defense.

These two case studies allow us to track the capacity changes in the Ministry of Defense from two perspectives: first, the lending of material support to the Armed Forces of Ukraine (first case study) vs. human resources to the defense institution (second case study) and secondly, as operating inside vs. outside the institution. The first case study is focused on civil society as independent from the state, whereas the second case study is the example of a hybrid "cohabitation" of civil society and the state. While the second case does not allow for a "pure" separation of civil society from the state, it is symptomatic of a conflict environment in which Ukraine found itself. According to Marchetti, ${ }^{37}$ when a state does not exist or is weak, fragmented or failing, the already blurred lines separating the state from civil society become even fuzzier. The coexistence between civil society and the state assumes a hybrid form, with the governance of "what is old and what is new, of what is local and what is international (MacGinty 2011), of what is civil and what is not, all of which conflict, co-exist and cooperate across the civil society, market and state spheres." ${ }^{38}$ Since the people who came to the Ministry of Defense as a part of "Volunteer Force" were selected exactly because of their volunteer experience, one could argue that this is a good case for tracing the effect of volunteers on institutional transformations.

The data for analysis is open source materials and public interviews of volunteers as well as face-to-face interviews ( $\mathrm{n}=6$, conducted in Kyiv in November 2016 and April 2017) with the representatives of the selected five volunteer organizations and members of "Volunteer Force," some of which are anonymized. While quantitative and qualitative open source data (monitoring indices, budget data, procurement data, legislative amendments, etc.) is important in assessing the capacity change in the Ministry of Defense, in-depth interviews provide a revealing glimpse into the nuances of the volunteers' relationship with the state and underlying causes of clear patterns. Importantly, this article places emphasis on the civil society perspective, while state perception of the volunteers' impact on itself remains outside the scope of this research.

36 Retrieved from the cached version of the organization's website http://archive.is/ZoSig (accessed December 8, 2017).

37 Raffaele Marchetti, "Civil Society in Conflicts: From Escalation to Militarization," Russia in Global Affairs, October 28, 2015, accessed December 20, 2017, http://eng.globalaffairs.ru/valday/Civil-societyin-conflicts-from-escalation-to-militarization-17781.

38 Rana Khalaf, "Governance without Government in Syria: Civil Society and State Building during Conflict," Syria Studies 7.3 (2015): 42. 


\section{Volunteer Organizations Supporting the Armed Forces: Analysis of Dynamics}

\section{Dynamics within the Volunteer Movement}

The overview of the evolution of the volunteer organizations (VO) performed for this study shows that there is a considerable decrease in the number of volunteer organizations in 2016-2017 in comparison to 2014-2015, when their activity peaked. Two reasons account for this: partial satisfaction of basic military needs and decrease in public donations. By early 2016 , the volunteers acknowledged that key basic necessities like bullet-proof jackets, helmets and uniforms were already provided by the state, so volunteer involvement was no longer needed. ${ }^{39}$

As for public donations, according to "The People's Home Front" volunteer Roman Sinitsyn, individual public donations decreased considerably after the signature of the "Minsk-2" conflict settlement plan in February 2015 and dried up almost completely in September 2015 . As a result, numerous smaller volunteer groups, e. g. "Polissia guerillas" ("Poliski partyzany"), a volunteer group in Ternopil region which sewed camouflage, seized operation. ${ }^{40}$ Donations to the remaining organisations also changed: coming less from small, highly numerate donations (e. g. 50, 100, 200 UAH), and increasingly from a stable and relatively small cohort of individual and business donors. ${ }^{41}$

As smaller and less technologically-savvy organizations ceased their operation altogether, a fall in donations and a partial improvement in basic military needs also affected the operation of larger organizations. For example, the core team of "The People's Home Front" had decreased from 30-40 people in 2014 to $4-5$ in 2017.42 The core team of "Wings of Phoenix" in 2017 were just two persons, and at the time of research, were unsure if they would continue operating to

39 Kateryna Pieshko, "Volonter Vitalii Deineha: Nashykh divchat, yaki pryvezly prytsil, 'aidarivtsi' nich trymaly z mishkamy na holovi [Volunteer Vitalii Deineha: 'Aidar' Battalion Soldiers Kept Our Girls, Who Had Brought the Breech-sights for Them, with Bags on Their Heads for a Whole Night]," Glavcom, March 2, 2016, accessed December 20, 2017, http://glavcom.ua/interviews/331473-volontervitalij-dejnega-nashih-divchat-jaki-privezli-pritsil-\%C $2 \% A B a j d a r i v t s i \% C ~ 2 \% B B-n i c h-t r i m a l i-z-$ mishkami-na-golovi.html.

40 Mykhailo Hlukhovskyi, "Volonter Roman Synitsyn: Ye kupa ludei, yaki spalyly po 5-6 tankiv [Volunteer Roman Synitsyn: There are Many People, Who Have Burnt 5-6 Tanks]," Glavcom, September 3, 2015, accessed December 20, 2017, http://glavcom.ua/interviews/13129o-volonterroman-sinitsin-je-kupa-ljudej-jaki-spalili-po-5-6-tankiv.html.

41 Mykhailo Hlukhovskyi, "Volonter Iryna Huk: Soldatski aptechnky dosi ukomplektovani zhhutamy chasiv pershoi svitovoi [Volunteer Iryna Huk: The Soldiers' First-aid Kits are still Equipped with Bondage Harnesses Dating Back to World War I]," Glavcom, March 21, 2017, accessed December 20, 2017, http://glavcom.ua/interviews/volonter-irina-guk-soldatski-aptechki-vid-derzhavi-dosiukomplektovani-dzhgutami-chasiv-pershoji-svitovoji-404566.html; Pieshko, "Volonter Vitalii Deineha."

Author's interview with a team member of “The People's Home Front," April 10, 2017. 
the end of $2017 .{ }^{43}$ A regional branch of "Wings of Phoenix" disbanded due to a lack of resources and purpose, with its members moving to join Ukraine's regular armed forces. ${ }^{44}$

Above all, key figures "resigned" from the volunteer activities, including Roman Sinitsyn and Heorhii Tuka ("The People's Home Front"), Olha Reshetilova ("Come Back Alive"), Tetiana Rychkova ("Wings of Phoenix"), etc. Some went back to their lives before full-time volunteering, some went to occupy positions in the government (Heorhii Tuka) or parliament (Tetiana Rychkova). "Come Back Alive," under the leadership of Vitalii Deineha, is being transformed into a NGO in order to qualify for Western public and private grants, as well as to conduct formal charity work once the conflict is resolved. ${ }^{45}$

However, state substitution continued in areas where VO filled a unique, often high-tech niche which the state otherwise would not be able to fill. Examples include the provision of thermal imaging cameras, drones, tablets with ballistic software and electronic maps, development of artillery fire control systems, etc. According to one of the most renowned figures Vitalii Deineha, volunteers provided over $50 \%$ of the whole stock of thermal imaging cameras to the Ukrainian armed forces in the conflict zone. ${ }^{46}$ Another was the provision of professional military training. A prominent example is the sapper training course, developed by "Come Back Alive" and triggered by an incident when several members of Ukraine's military brigades failed to identify a mine and died upon its detonation. ${ }^{47}$ Another example is a sniping course organized by a volunteer organization "Combat.ua."

It is also noteworthy that the "next stage" after the procurement and supply for some volunteer organizations was not only repairs but also audits of military supplies, thus improving transparency and accountability for the supplies received. ${ }^{48}$

As volunteer Roman Sinitsyn summed up in his own farewell FB-post in 2016, the "purchase-delivery assistance" was no longer needed. Instead, as the conflict continued and veterans came back from the frontline, new needs arose. In Sinitsyn's words, more focus was required on "rehabilitation, psychological and legal support, medical treatment, trainings, repairs, big infrastructural and sector-specific high-tech projects." ${ }^{99}$ Indeed, the activities of some

43 Author's interview with a team member of "Wings of Phoenix," April 4, 2017.

44 Author's interview with a team member of "Wings of Phoenix," April 4, 2017.

45 Pieshko, "Volonter Vitalii Deineha."

46 Pieshko, "Volonter Vitalii Deineha”; in September 2015 Roman Synitsyn also claimed that all thermal imaging cameras at the frontline were provided by volunteers, see Hlukhovskyi, "Volonter Roman Synitsyn."

47 "Bek-ofis armii."

48 "Volonter Vitalii Deineha: ya ne chekaiu udaru v spynu vid SBU pry nynishnomy holovi [Vitalii Deineha, a Volunteer: I Don't Expect a Stab in the Back under the Current SSU Head]," 5 Channel, February 3, 2016, accessed December 20, 2017, https://www.5.ua/interview/volonter-vitalii-deinehaya-ne-chekaiu-udaru-v-spynu-vid-sbu-pry-nynishnomu-holovi-10526o.html.

49 "Roman Synitsyn: chomu ya ydu z volonterstva, zibravshu 4,4 mln [Roman Synitsyn: Why I am Dropping Out of Volunteering After Having Raised 4,4 mln UAH]," Novynarnia, January 21, 2016, accessed December 20, 2017, http://novynarnia.com/2016/o1/21/roman-sinitsin-chomu-ya-ydu-zvolonterstva/. 
organizations evolved to cover these needs, e. g. professional psychological support to troops at the frontline ("Come Back Alive"), development of regeneration systems for seriously injured troops ("The People's Project") and care for families of dead soldiers ("The People's Home Front"). Thus, state substitution ceased in the basic realm of provision and procurement, but continued in more nuanced and high-tech areas.

\section{Volunteer Organizations and Interaction with the State}

In a number of cases, VO strengthened the state by increasing its capacity. One such example is the sapper training course developed by "Come Back Alive" which was later developed into programme jointly prepared by the volunteers and state instructors and was included into the official curriculum of the Ukrainian Airmobile Forces. ${ }^{50}$ The "success cooperation story" of "The People's Project" is the development of concept for anti-accumulative screens for armored vehicles, while the engineers of the research institute at the Ministry of Defense increased its effectiveness four-fold. ${ }^{51}$

However, in a range of situations, volunteers failed to change old practices. For example, the key problem for volunteers was their operation in a legal "grey zone," bypassing or even acting against the current outdated legislation. For example, volunteers would import vehicles for the military on a duty-free basis, which contravenes Ukrainian law. Paradoxically, the scheme was only possible with the Security Service of Ukraine (SSU) direct consent and support (the SSU would request Ukraine's Customs and Border Services to let the vehicles pass the border). ${ }^{52}$ However, there was no mechanism for registration of such illegal equipment at the military units and hence, no accountability for them, either by volunteers (who handed them over to the military), or by the military themselves (because they were not responsible for them officially). ${ }^{53}$

This problem was also related to other types of equipment provided by the volunteers, e. g. drones. According to volunteer Yurii Kasianov, the frontline would only be equipped with drones provided by either volunteers or by sponsors to individual squads, bypassing the Ministry of Defense, for fear of the equipment not reaching the frontline. The Ministry of Defense would not envisage the staff positions for troops performing the unmanned reconnaissance. As a result, whole units of unmanned aviation would operate, while officially being registered as grenade launchers or machine-gunners. ${ }^{54}$

$50 \quad$ Pieshko, "Volonter Vitalii Deineha."

51 "Bek-ofis armii."

$5^{2} \quad$ Hlukhovskyi, "Volonter Roman Synitsyn."

53 Dmytro Lykhovyi, "Oleksii Sikharulidze: na promzoni strashnishe, nizh u DAPi. Ale dopomahaty treba 'nerozkruchenym' pozytsiiam [Oleksii Sikharulidze: In Promzona (battlefield in the town of Avdiivka - K.Z.) It Is Scarier than in Donetsk Airport. But Aid Should Be Directed to Less 'Promoted'

Positions]," Novynarnia, December 5, 2016, accessed December 20, 2017, http://novynarnia. com/2016/12/o5/oleksiy-siharulidze-na-promzoni-strashnishe-nizh-u-dapi-ale-dopomagati-trebanerozkruchenim-pozitsiyam/.

Yurii Sandul,"Yurii Kasianov, volonter: u proekti — merezhevi bezpilotnyky. Tse vzhe na kshtalt kolektyvnoho rozumu [Yurii Kasianov, a Volunteer: Network' Drones Are Being Developed. This is 
Against the backdrop of widely reported bureaucratic reluctance to accept and register the technological resources provided by volunteers (de facto already in use at the frontline), the volunteers were continually at risk of being charged with criminal or administrative offences. This legal conflict - with volunteers strengthening the state's defense capacity by effectively breaking the state's law — reached its pinnacle when the Prosecutor's General Office opened a criminal case against one of the volunteers, David Arakhamia. This triggered a flashmob on Facebook, with volunteers publicly declaring things they had had to smuggle in order to support the armed forces. ${ }^{55}$

According to the volunteers, the bulk of their communication and needs assessments are effected directly with the frontline units and not through the Ministry of Defense, allowing them to identify the armed forces' needs first-hand. In addition, the volunteers also claimed that the Ministry of Defense was unable to file a specific request with terms of reference for any equipment, with volunteers simply being more aware of military needs than the Ministry of Defense itself.

They would also point out to the problem that the armed forces themselves found it easier to work with volunteers who would provide them with the necessities quickly, efficiently and without any bureaucratic hurdles. Hence, they preferred to file requests with volunteers rather than with the Ministry of Defense, even if the goods requested were available in state warehouses. ${ }^{56}$ The volunteers believe that the Ministry of Defense ultimately became accustomed to relying on the volunteers. ${ }^{57} \mathrm{All}$ in all, the volunteers are aware of their state-substitution functions and of its unsustainability in the longer term. ${ }^{58}$ The farewell FB-post one of the volunteers Pavlo Kashchuk ("Combat.ua") resonated with numerous other volunteers' moods:

We had to do everything to hold until the reforms start, until the new correct processes are launched, until the state learns to sustain the military with its own resources. We were so focused on these tasks that we got carried away and didn't even notice a year and a half passing while the system didn't start

Something Like Collective Intellect]," Ukrinform, June o2, 2016, accessed December 20, 2017, https:// www.ukrinform.ua/rubric-society/2027759-urij-kasanov-volonter.html.

55 Anastasiia Rinhis, “'Volonterskii desant' demobilizirovan. Ideolog proekta David Arakhamia ob eksperimente v MO ['Volunteer Force' Is Demobilized. Project Ideologist David Arakhamia Tells about the Experiment at the Ministry of Defense]," Ukrainska Pravda, November 5, 2015, accessed December 20, 2017, http://life.pravda.com.ua/society/2015/11/5/202712/.

56 Hlukhovskyi, "Volonter Iryna Huk."

57 Pasha Kashchuk, "Segodnia chutok znakovyi den dla menia. Zakryl svoiu volonterskuiu kartu [Today Is a Bit Significant Day for Me. I Hhave Closed My Volunteer Bank Account]," Facebook, January 4, 2016, accessed December 20, 2017, https://www.facebook.com/photo. php?fbid=1029887747033781\&set=a.289451027744127.69361.100000376963441\&type=3\&aid=13P92 Y. wghot.

$5^{8}$ Author's interview with a "People's Home Front" volunteer, April 10, 2017. 
working. ... And the volunteers are also partially to blame. Alas, we relaxed the Armed Forces, relaxed the government, relaxed the state..$^{59}$

\section{Volunteer Organizations as Watchdogs}

While some volunteer organizations in question would not officially define their goals as advocacy and democratic oversight of the defense sector, they would ultimately engage in advocating changes and reform in state structures. One of the simplest ways of advocating for change and raising public awareness is to engage social networks: Facebook profiles of some of the most popular volunteers would be followed by tens of thousands of people, ${ }^{60}$ including the President and the Minister of Defense themselves. ${ }^{61}$ Such readership following, combined with the level of trust towards the volunteers, ${ }^{62}$ would lead to a multiplying effect on media and public engagement. Thus, for example, one of the interviewed volunteers reported that conducting more formal advocacy on behalf of their VO was not their intention. However, he reported a case when he posted a picture of a truck full of rotten potatoes at the frontline that immediately provoked an outcry from the public and reaction from the Ministry of Defense. Alternatively, advocacy through social networks would be employed when non-public advocacy efforts bore no fruit. ${ }^{63}$

For their part, "Come Back Alive" and "The People's Project" adopted advocacy as a systemic activity within their organizations. Vitalii Deineha pointed to two cases of direct effect of volunteer efforts to influence decision-making in military appointments ${ }^{64}$ as well as to other unsuccessful cases. ${ }^{65}$ One of "The People's Project" plans is to add one more dimension- "Reforms" - to the three currently existing dimensions of their activities ("Army," "Health protection" and "Social projects"). The aim is to influence change at a systemic level with the development of legislation, holding of events, etc. ${ }^{66}$ However, at the time of writing, this still remains a mere prospect. The

59 Author's interview with a "People's Home Front” volunteer, April 10, 2017.

6o For example, as of April 2017 Facebook account of Roman Synitsyn is followed by over 41 ooo people (https://www.facebook.com/romabra), Vitalii Deineha's account has over 30 ooo followers (https:// www.facebook.com/Deynega).

61 Author's interview with a member of the Volunteer Council at the Ministry of Defense, December 17, 2016.

62 According to GfK Ukraine, 61\% of Ukrainians trusted volunteers in 2015. See http://www.fair.org.ua/ content/library_doc/fair_gfk_eng.pdf.

63 Hlukhovskyi, "Volonter Roman Synitsyn.”

64 "Poroshenko poiasnyv, za shcho zvilnyv Haiduka z posady komandyvacha VMS [Poroshenko Explained Why He Had Fired Haiduk from the Position of the Commander of the Ukranian Navy]," Censor.net, April 16, 2016, accessed December 20, 2017, http://ua.censor.net.ua/n384669.

65 Pieshko, "Volonter Vitalii Deineha."

66 Liudmyla Horpynych, "Volonter Maksym Riabokon: my stilky zrobyly, shcho zalyshylosia shche zovsim trokhy - i viina zakinchytsia [Volunteer Maksym Riabokon: We Did So Much, The War Will End Very Soon]," 5 Channel, June 10, 2016, accessed December 20, 2017, http://www.5.ua/interview/ maksym-riabokon-volonter-116682.html. 
VO existent advocacy activities, while being secondary aim of the volunteer organizations (if at all), focused on the ability of the state to perform, rather than to reform.

\section{"Volunteer Force" at the Ministry of Defense: Changing the System from Within}

The "Volunteer Force" (VF) entered the Ministry of Defense as a pilot project in November 2014. Taking into consideration the remarkable successes of volunteers in supporting the armed forces, the idea was conceived by the Minister of Defense Stepan Poltorak and Yurii Biriukov, a "Wings of Phoenix" volunteer who had been appointed as advisor to the President in August 2014. The name of the initiative was meant to reflect the "field", i. e. frontline aid experience of the volunteers. The team consisted of nine people, including Biriukov, two other "Wings of Phoenix" volunteers, Diana Petrenia and Nelli Stelmakh, and six more people, selected through an open competition (three, however, soon left for various reasons). The competition was coordinated by David Arakhamia, then-Head of Volunteer Council at the Ministry of Defense and the founder of "The People's Project", and drew more than 400 applications.

In contrast to volunteers like Vitalii Deineha, who felt that he could be most useful outside the Ministry of Defense, the VF members were motivated by the possibility of effecting change from within. One of the VF members, Bohdan Kovalev explained his motivation as follows: "I could not have gone to the Ministry and go on collecting tens of thousands of hryvnias. However, here I can observe how billions are spent and help do it effectively." ${ }^{67}$ Nelli Stelmakh was inspired to join after reading Francis Fukuyama's interview with a Ukrainian journalist Mustafa Nayem, in which he encouraged civil society to go into public institutions and change them from within. ${ }^{68}$

Overall, the VF members perceived their joining the Ministry of Defense as a form of "conscription" rather than a career chance or promotion. For example, some of them had to move to Kyiv from other cities, leaving their families and former jobs behind. ${ }^{69}$

The modus operandi of the "Volunteer Force" at the Ministry of Defense immediately acquired numerous "hybrid" traits, allowing its members to work inside the Ministry while not becoming part of formal procedures. Thus, all but one of them avoided official appointment as public servants. The advantage of this status was the avoidance of bureaucratic traps and limitation of responsibilities. Instead, the VF members were hired as "technical managers", whereas they worked in practice as consultants and project managers. As one of the members of the "Volunteer Force" admitted, she did not even know which department of the Ministry she formally belonged to. ${ }^{70}$ Out of all the team only one person, Nelli Stelmakh, occupied a civil servant position, working as a Head of the Department of public procurement at the Ministry of Defense. Importantly too, the ex-volunteers who were engaged with the Ministry of Defense's

67 Rinhis, Tytysh, "Virus' v ministerstve oborony."

68 Rinhis, Tytysh, "Virus' v ministerstve oborony."

69 Rinhis, Tytysh, "Virus' v ministerstve oborony." 
work "distanced" themselves from the state framework, negating their involvement in formal procedures of the Ministry and any "ownership" of same..$^{71}$

While their official job mandates included very little if any decision-making, the VF members exerted influence through high-level support, namely by submitting an idea to the Minister or the Deputy Minister, who would then issue authorizations to be passed down to the mid-bureaucratic level in charge of implementation of the specific tasks. ${ }^{72}$ The VF members' salaries would be also paid in an indirect way: having no wages as civil servants, the families of the VB members received a monthly pay of 7 ooo to 15 ooo UAH from public donations under a project established by "The People's Project".

The initial weeks of the VF were chaotic and lacked coordination, being without a formal programme or agenda upon entering the Ministry of Defense. According to Yurii Biriukov, they would select the activities in which to get involved almost "by tossing a coin." 73 However, the choices were primarily limited to the most "sore" and challenging domains at the Ministry, namely, provision and procurement. Several reasons account for this. Firstly, as described above, corruption and mismanagement of funds was rampant in the Ministry of Defense, which took its toll on provision and procurement. Second, provision and procurement were one of the principal spheres of volunteer field engagement, so this was the best expertise they could lend to the Ministry. ${ }^{74}$ Hence, the first six team members of the "Volunteer Force" were tasked with material and food provision and public procurement. However, it would be wrong to perceive the "Volunteer Force" as an established and coordinated team: the title rather refers to the name of the project under which people would work in different divisions and separately from each other, with each member of the team defining his or her goals independently. ${ }^{75}$

As reported by ex-volunteers, they were treated with suspicion by mid-level bureaucrats upon joining the Ministry of Defense. The newcomers were informally called "supervisors" or "prosecutors" by the Ministry's mid-level staff. However, when they saw that the "Volunteer Force" actually managed to introduce new rules and break away from formal schemes, as well as to communicate directly with the Minister, the Presidential Administration and the Security Service of Ukraine, some mid-level public servants started reporting violations in their departments. ${ }^{76}$ Similar to the external volunteers, the "Volunteer Force" chose not to criticise the Ministry

71 Halyna Tytysh,"Otladka mekhanizma. Aleksei Lipiridi o novoi gruppe po vyiavleniu problem na fronte, boitsakh i volonterakh [Setting up the Mechanism. Aleksei Lipiridi about the New Group on Checking the Problems at the Frontline, Soldiers and Volunteers]," Ukrainska Pravda, 16 August 2015, accessed December 20, 2017, http://life.pravda.com.ua/society/2015/o8/16/198654/. Marta Puhach, "Perelamaty chynovnyka. Yak zhmenka volonteriv zmusyla pratsiuvaty Minoborony. Ta vse mozhe povernutysia nazad [To Break a Bureaucrat. How a Bunch of Volnteers Made the Ministry of Defense Work. However, It Can All Be Reversed]," Texty, January 28, 2017, accessed December 20, 2017, http://texty.org.ua/pg/article/editorial/read/64837/Perelamaty_chynovnyka_Jak_ zhmenka_volonteriv_zmusyla_pracuvaty.

73 Author's interview with Yurii Biriukov, November 23, 2016.

74 Author's interview with Yurii Biriukov, November 23, 2016.

75 Puhach, "Perelamaty chynovnyka."

76 Rinhis, “Volonterskii desant' demobilizirovan.” 
publicly. According to Bohdan Kovalev, their task was "not to discredit the Ministry of Defense but to establish good working cooperation between the departments, so that the system could function normally". Even after resigning from her position, Nelli Stelmakh refused to criticise the Ministry publicly. ${ }^{77}$

The "Volunteer Force" approach to reforms was tactical rather than strategic. No reform matrix existed in the Ministry of Defense back in 2014, and it was not until June 2016 that Strategic Defense Bulletin, featuring specific reform plans and indicators of its implementation, was developed and published. So, members of the "Volunteer Force" adopted the tactics of "quick victories," introducing specific projects which could be completed within one year and "fill in" the most urgent gaps. ${ }^{78}$ Nelli Stelmakh admitted that, working six days per week, 14-16 hours per day, she could only handle operational tasks, whereas reforms were not her goal. One of the key achievements of ex-volunteers was the introduction of the system of public electronic tenders, Prozorro, Ukraine's hallmark corruption-fighting "success story." The Ministry of Defense was the first ministry which not only fully adopted Prozorro, but also was the first to use it in trial mode, ${ }^{79}$ before its official launch and obligation to use in all public procurement tenders. Other achievements include the pilot project for new catering systems for the military, development of the new specifications for providers, introduction of the electronic property register, launching a series of projects on storehouses automation. They also concluded numerous contracts with new providers, cutting off uncompetitive and corrupt schemes: in the words of Nelli Stelkmakh, while in 2013 the Ministry of Defense department of public procurement featured 31 agreements, by the end of 2015 the number of agreements for material, food and fuel and lubricants procurement reached $850 .{ }^{80}$ As a result, Ukraine's Minister of Defense Stepan Poltorak admitted that the "Volunteer Force" provided crucial assistance in public procurement, both by administering procedures and informing the Minister, in contrast to some "impartial" bureaucrats of the Ministry. ${ }^{81} \mathrm{He}$ also confirmed that the "Volunteer Force" was able to move forward the logistics, provision and equipment as key reform spheres, ${ }^{82}$ and by the end of 2015 , both independent volunteers and Ministry of Defense top officials confirmed that the basic needs of food, uniform and footwear had been satisfied. ${ }^{83}$

77 "Volonter Nelli Stelmakh zvilnylasia z Minoborony [Volunteer Nelly Stelmakh Resigned from the Ministry of Defense]," Liga.net, November 6, 2015, accessed December 20, 2017, http://news.liga.net/ ua/news/politics/7039732-volonter_nell_stelmakh_zv_lnilasya_z_m_noboroni.htm.

78 Puhach, "Perelamaty chynovnyka."

79 Author's interview with Yurii Biriukov, November 23, 2016.

$80 \quad$ Koval, "Nelli Stelmakh."

81 Sonia Koshkina, "Stepan Poltorak: 'Chekaty, koly vidnovytsia myr, chasu nemaie. I prava na pomylku nemaie' [Stepan Poltorak: “There is No Time to Wait Until Peace Restores. And We Have No Right for a Mistake]," Livyi Bereh, October 9, 2016, accessed December 20, 2017, https://lb.ua/ news/2016/10/o9/347382_stepan_poltorak_chekati_koli.html.

82 Koshkina, "Stepan Poltorak."

83 Dmitrii Syniak, "My ostanovili krovotechenie v organizme armii_zamministra oborony Yurii Husev [We Have Stopped the Hemorrhage in the Army's Body - Yurii Husev, Deputy Minister of Defense]," Focus, November 10, 2015, accessed December 20, 2017, https://focus.ua/country/339116/. 
The "Volunteer Force" project paved the way for the Project Office of Reforms at the Ministry of Defense, launched in August 2015. Its website reads:

The "Volunteer Force" lays the foundation of the institutional changes in the Ministry of Defense of Ukraine. As of early 2015 the reforms and novelties acquired systemic character. In August 2015 the Project Office of Reforms was launched according to the decree of the Minister of Defense. Its aim is to conduct a comprehensive and professional process of the reforming of the Ministry of Defense. ${ }^{84}$

The Project Office avails of over 40 personnel, some of whom come from the "Volunteer Force." The "Volunteer Force" experiment demonstrated mixed results. On the one hand, the experiment was unprecedented, contributing to the greatest openness and accountability of the Ministry of Defense since Ukraine's independence: VF members were extremely open to media, giving dozens of interviews and posting on social media. However, they lacked capacity to develop a legal basis with which to prove specific violations and abuses among civil servants, and thus found it very difficult to bring corrupt members of the system to justice. ${ }^{85}$ In addition (and somewhat ironically), their crystal-clear transparency and accountability generated false expectations regarding their potential and the level of change they could make. As a result, the "Volunteer Force" was criticised by the general public for lack of impact. ${ }^{86}$

A number of important changes and pilot projects were started. However, the work of the "Volunteer Force" could not lead to systemic change at all levels. Also, in some cases resistance to change won over the ex-volunteers' reformist efforts. Stelmakh also admitted that she left her position because of the threefold pressure: from the private business sector, which suffered from her corruption-stemming efforts; bureaucratic inertia; and lack of a team. ${ }^{87}$ She agreed that the "Volunteer Force" was the right thing to do, but evaluated the project as neither successful, nor unsuccessful. ${ }^{8}$

As seen today, the VF mixed results can be explained by a number of factors, both exogenous and endogenous to civil society. On the one hand, resistance of interest groups (benefiting from old corrupt schemes) and mid-level bureaucratic inertia blocked VF efforts. On the other, VF members lacked vision, strategy, professional capacities and resources, being too few to push reforms through and realizing the unsustainability of their sporadic reform efforts.

84 Ministry of Defense of Ukraine. Project Reform Office, "History, Mission and Role of the Reform Project Office," accessed June 8, 2017, https://defense-reforms.in.ua/reforms-office.

85 Anastasiia Rinhis, “Volonterskii desant' demobilizirovan.”

86 Anastasiia Rinhis, “Volonterskii desant' demobilizirovan."

87 Author's interview with Nelli Stelmakh, November 18, 2016.

88 Anastasiia Rinhis, “Volonterskii desant' demobilizirovan." 


\section{Conclusion}

This article analyzed the effects of the volunteer participation on defense sector reform in Ukraine. In particular, it aimed to answer whether the volunteer movement led to institutional strengthening in the Ukrainian defense state structures or, to their weakening at times of state fragility.

The research revealed the double-edged effect of volunteer activities on defense reform. The analysis of the empirical data suggests that volunteer organizations contributed to both strengthening the defense state capacities and weakening them primarily by substitution for the state, which is typical for fragile states. On the one hand, state capacity has increased in those areas of provision and procurement, which were relatively easy to fill in. This is also demonstrated by the fact that those volunteer organizations which provided for basic military needs, e. g. food, clothes and basic ammunition, ceased to exist. At the same time, weakening effects were also observed: firstly, by providing services more efficiently than the state (even those which the state ultimately regained the ability to provide). This was found to have induced the military to rely on volunteers rather than demand the state to change its practices. Also, substitution for the state by the volunteers is further observed in numerous spheres which regard to high technologies. Overall, civil society managed to strengthen the state in those areas where state expertise was relatively easy to ultimately regain, but took over the state services in those areas where high profile capacity was required. This finding can also be exemplified by the evolution of the volunteer movement itself: while small volunteer initiatives stopped their work altogether, larger forces reoriented themselves from filling in basic needs of the frontline like food and clothes, to offer more niche services like psychological treatment or high tech developments.

In the case of lending human resources, the effect of volunteer participation is similar: the volunteers fulfilled a crucial function in keeping the Ministry "afloat" and performing its basic functions. However, they failed to bring systemic change to the Ministry. In other words, they created "a window of opportunity" for this change to take place but didn't bring this change about by themselves. However, their hybrid operation of low-level, technical-type personnel, combined with high impact on decision-making, created a precedent in the history of Ukraine's security sector reform.

Another important finding for the research is that the volunteers, both within and outside the Ministry of Defense, continued to fulfill the "democratic oversight" function, contributing to the "unprecedented openness" of the Ministry. ${ }^{89}$ Alongside substituting for the state, they became sources of information on the state defense capacity for the public, mainly through social networks and media, thus generating public pressure on the state to perform, but not to reform. In other words, the advocacy and watchdog functions of civil society were reduced to pressing the state to fill in the most immediate needs, rather than introduce serious reforms and change procedures.

The reasons as to why volunteers succeeded in transforming the state in some but not all cases are numerate. On the one hand, interest groups and bureaucratic inertia blocked some of civil society efforts. On the other, a large share of the volunteers perceived their activities as

89 Koshkina, "Stepan Poltorak." 
temporary, aimed at filling the basic needs of the military rather than implementing a long-term strategy, and therefore dropping out when they felt their immediate mission was complete. This reflects the findings of Kryshtapovych that "volunteers typically do not contemplate much about the future of the movement since they focus all their capacities on meeting current needs." 90

This article is, however, only a modest effort to capture the vast realm of state-society relations which post-Euromaidan Ukraine can offer to global academic research. Further research is needed to identify the effect of other types of volunteer organizations on state capacity, from social projects like support to IDPs, to further areas e. g. media, ICT, etc. A comparative analysis of the effect of civil society efforts on state capacity in different functions could be an important contribution to academic debate on the issue, revealing valuable new theories.

\section{Bibliography}

Barnes, Catherine. Agents for Change: Civil Society Roles in Preventing War and Building Peace. The Hague: European Centre for Conflict Prevention, 2006.

"Bek-ofis armii [Army's Back Office]." Ukrainska Pravda, 31 July 2015. Accessed December 20, 2017. http://www.pravda.com.ua/cdn/cd1/2015year/back_office/index.html.

Brown, Graham. Civil Society Building in Post-Conflict Countries. Leuven: Centre for Research on Peace and Development Working Paper, 2015.

Caparini, Marina. "The Relevance of Civil Society." In Security Sector Reform: Potentials and Challenges for Conflict Transformation, edited by Clem McCartney, Martina Fischer and Oliver Wils. Berlin: Berghof Research Center for Constructive Conflict Management, 2004.

Caparini, Marina. Civil Society and Democratic Oversight of the Security Sector: A Preliminary Investigation. Geneva: The Geneva Centre for the Democratic Control of Armed Forces (DCAF) Working Paper 132, 2004.

Caparini, Marina and Philipp Fluri,. "Civil Society Actors in Defense and Security Affairs." In Civil Society and the Security Sector: Concepts and Practices in New Democracies, edited by Marina Caparini, Philipp Fluri, Ferenc Molnar. Berlin: LIT Verlag, 2006.

Cottey, Andrew, Timothy Edmunds and Anthony Forster. "The Second Generation Problematic: Rethinking Democracy and Civil-Military Problematic." Armed Forces and Society 29.1 (2002): $31-56$.

Democratic Initiatives Foundation. "32.5\% ukraintsiv osobysto perekazaly svoi koshty na rakhunky ukrainskoi armii [32.5\% of Ukrainians Personally Donated Money to the Ukrainian Armed Forces]." October 21, 2014. Accessed December 20, 2017. http://dif.org. ua/article/325-ukraintsiv-osobisto-perekazali-svoi-koshti-na-rakhunki-ukrainskoi-armiiselyani-vidznachilis-vishchoyu-dobrochinnistyu-anizh-miski-zhiteli.

Fischer, Martina. Civil Society in Conflict Transformation: Ambivalence, Potentials and Challenges. Berlin: Berghof Research Center for Constructive Conflict Management, 2006.

Fowler, Alan. "The Role of NGOs in Changing State-Society Relations: Perspectives from Eastern and Southern Africa." Development Policy Review 9 (1991): 53-84.

90 Oleksandra Kryshtapovych, "State and Civil Society Relations in the Conditions of Military Crises: The Case of Defense Volunteer Movement in Ukraine" (Master's Thesis, 2016), 43. 
Gf K. "Volonterskyi rukh v Ukraini [Volunteer Movement in Ukraine]." December 5, 2014. Accessed December 20, 2017.https://www.gfk.com/fileadmin/user_upload/dyna_content_ import/2015-o9-01_press_releases/data/ua/Documents/Presentations/report_vyshlisky. pdf.

Government Defense Anti-Corruption Index. "Ukraine. 2015." Accessed April 21, 2017. http:// government.defenceindex.org/countries/ukraine/.

Hlukhovskyi, Mykhailo. “Volonter Iryna Huk: Soldatski aptechnky dosi ukomplektovani zhhutamy chasiv pershoi svitovoi [Volunteer Iryna Huk: The Soldiers' First-aid Kits are Still Equipped with Bondage Harnesses Dating Back to World War I]." Glavcom. March 21, 2017. Accessed December 20, 2017.

http://glavcom.ua/interviews/volonter-irina-guk-soldatski-aptechki-vid-derzhavi-dosiukomplektovani-dzhgutami-chasiv-pershoji-svitovoji-404566.html.

Hlukhovskyi, Mykhailo. "Volonter Roman Synitsyn: Ye kupa ludei, yaki spalyly po $5^{-6}$ tankiv [Volunteer Roman Synitsyn:There are Many People, Who Have Burnt 5-6 Tanks]." Glavcom. September 3, 2015. Accessed December 20, 2017. http://glavcom.ua/interviews/13129ovolonter-roman-sinitsin-je-kupa-ljudej-jaki-spalili-po-5-6-tankiv.html.

Horielov, Denys, and Oleksandr Korniievskyi. Volonterskyi rukh: svitovyi dosvid ta ukrainski hromadianski praktyky [Volunteer Movement: Global Experience and Civil Practices in Ukraine]. Kyiv: National Institute of Strategic Studies, 2015. Accessed December 20, 2017. http://web.archive.org/web/20160415001030/http://www.niss.gov.ua/content/articles/files/ volonter-697e4.pdf.

Hyden, Goran. "Civil Society, Social Capital and Development:Dissection of a Complex Discourse." Studies in Comparative International Development 32.1 (1997): 13-30.

Khalaf, Rana. "Governance without Government in Syria: Civil Society and State Building during Conflict." Syria Studies 7.3 (2015): 37-72.

Koshkina, Sonia. "Stepan Poltorak: 'Chekaty, koly vidnovytsia myr, chasu nemaie. I prava na pomylku nemaie' [Stepan Poltorak: "There is No Time to Wait Until Peace Restores. And We Have No Right for a Mistake]." Liryi Bereh, October 9, 2016. Accessed December 20, 2017. https://lb.ua/news/2016/10/o9/347382_stepan_poltorak_chekati_koli.html.

Koval, Inna. "Nelly Stelmakh: 'Maizhe dva roky my zhyvemo v umovakh voiennoho chasu, a pratsiuvaty prodovzhuiemo za zakonamy myrnoho' [We Have Been Living in the Conditions of War Time for Two Years But We are Still Working as if It Was Peaceful Times]." Forbes Ukraina, December 2, 2015. Accessed December 20, 2017.

http://forbes.net.ua/ua/nation/1406762-nelli-stelmah-majzhe-dva-roki-mi-zhivemo-v-umovahvoennogo-chasu-a-pracyuvati-prodovzhuemo-za-zakonam.

Kryshtapovych, Oleksandra. "State and Civil Society Relations in the Conditions of Military Crises: The Case of Defense Volunteer Movement in Ukraine” (Master's Thesis, University of Gothenburg, 2016).

Lessard, Danielle. "International NGOs and Statebuilding. The Case of Haiti, The Phanton State" (Master's Thesis, Lund University, 2010).

Lykhovyi, Dmytro. "Oleksii Sikharulidze: na promzoni strashnishe, nizh u DAPi. Ale dopomahaty treba 'nerozkruchenym' pozytsiiam [Oleksii Sikharulidze: In Promzona It Is Scarier than in 
Donetsk Airport. But Aid Should Be Directed to Less "Promoted" Positions]." Novynarnia, December 5, 2016. Accessed December 20, 2017. http://novynarnia.com/2016/12/o5/oleksiysiharulidze-na-promzoni-strashnishe-nizh-u-dapi-ale-dopomagati-treba-nerozkruchenimpozitsiyam/.

Marchetti, Raffaele. "Civil Society in Conflicts: From Escalation to Militarization." Russia in Global Affairs, October 28, 2015. Accessed December 20, 2017. http://eng.globalaffairs.ru/valday/ Civil-society-in-conflicts-from-escalation-to-militarization-17781.

Minakov, Mikhail. Corrupting Civil Society in Post-Maidan Ukraine? Carnegie Endowment for International Peace: Carnegie Moscow Centre, 2015.

Ministry of Defense of Ukraine. "Pres-reliz 13 chervnia 2014 roku 'Materialno-tekhnichne zabezpechennia viiskovosluzhbovtsiv Zbroinykh Syl Ukrainy' [Press release of June 13, 2014 'Material and Technical Provision of the Military of Ukraine's Armed Forces']." Accessed April 20, 2017. http://www.mil.gov.ua/dlya-zmi/pres-relizi/pres-reliz-13-chervnya-2014-roku. html.

OECD. OECD DAC Handbook on Security System Reform: Supporting Security and Justice. Paris: OECD, 2008.

Pieshko, Kateryna. "Volonter Vitaliy Deineha: Nashykh divchat, yaki pryvezly prytsil, 'aidarivtsi' nich trymaly z mishkamy na holovi [Volunteer Vitaliy Deineha: 'Aidar' Battalion Soldiers Kept Our Girls, Who Had Brought the Breech-sights for Them, with Bags on Their Heads for a Whole Night]." Glavcom, March 2, 2016. Accessed December 20, 2017. http://glavcom. ua/interviews/331473-volonter-vitalij-dejnega-nashih-divchat-jaki-privezli-pritsil\%C $2 \% A$ bajdarivtsi\%C 2\%BB-nich-trimali-z-mishkami-na-golovi.html.

Polyakov, Leonid."Defence and Security-Focused Think Tanks in Ukraine." In Civil Society and the Security Sector: Concepts and Practices in New Democracies, edited by Marina Caparini, Philipp Fluri, Ferenc Molnar. Berlin: LIT Verlag, 2006.

Posner, Daniel N. "Civil Society and the Reconstruction of Failed States." In When States Fail: Causes and Consequences, edited by Robert I. Rotberg. Princeton: Princeton University Press, 2004.

"Poroshenko poiasnyv, za shcho zvilnyv Haiduka z posady komandyvacha VMS [Poroshenko Explained Why He Had Fired Haiduk from the Position of the Commander of the Ukranian Navy]." Censor.net, April 16, 2016. Accessed December 20, 2017. http://ua.censor.net.ua/ n384669.

Puglisi, Rosaria. A People's Army: Civil Society as a Security Actor in Post-Maidan Ukraine. Rome: Istituto Affari Internazionali, 2015.

Puhach, Marta. "Perelamaty chynovnyka. Yak zhmenka volonteriv zmusyla pratsiuvaty Minoborony. Ta vse mozhe povernutysia nazad [To Break a Bureaucrat. How a Bunch of Volnteers Made the Ministry of Defense Work. However, It Can All Be Reversed]." Texty, January 28, 2017. Accessed December 20, 2017. http://texty.org.ua/pg/article/editorial/ $\operatorname{read} / 64837 /$ Perelamaty_chynovnyka_Jak_zhmenka_volonteriv_zmusyla_pracuvaty.

Rinhis, Anastasiia, and Halyna Tytysh. "'Virus' v ministerstve oborony ['Virus' in the Ministry of Defense]." Ukrainska Pravda, January 28, 2015. Accessed December 20, 2017. http://www. pravda.com.ua/cdn/cdi/2015year/volunteer/index.html. 
Rinhis, Anastasiia. “'Volonterskii desant' demobilizirovan. Ideolog proekta David Arakhamia ob eksperimente v MO ['Volunteer Force' Is Demobilized. Project Ideologist David Arakhamia Tells About the Experiment at the Ministry of Defense]." Ukrainska Pravda, November 5, 2015. Accessed December 20, 2017. http://life.pravda.com.ua/society/2015/11/5/202712/.

"Roman Synitsyn: chomu ya ydu z volonterstva, zibravshu 4,4 mln [Roman Synitsyn: Why I am Dropping Out of Volunteering After Having Raised 4,4 mln UAH]." Novynarnia, January 21, 2016. Accessed December 20, 2017. http://novynarnia.com/2016/o1/21/roman-sinitsinchomu-ya-ydu-z-volonterstva/.

"Samyie znachimyie volonterskiie initsiativy goda [The Most Significant Volunteer Initiatives of the Year]." The Insider, December 29, 2014. Accessed December 20, 2017. http://www. theinsider.ua/lifestyle/geroyam-slava-samye-znachimye-volonterskie-initsiativy-goda/.

Sandul, Yurii. "Yurii Kasianov, volonter: u proekti — merezhevi bezpilotnyky. Tse vzhe na kshtalt kolektyvnoho rozymy [Yurii Kasianov, a Volunteer: Network' Drones Are Being Developed. This is Something Like Collective Intellect]." Ukrinform, June 2, 2016. Accessed December 20, 2017. https://www.ukrinform.ua/rubric-society/2027759-urij-kasanov-volonter.html.

Schneckener, Ulrich. "Bosnien-Herzegovina. Der aufgezwungene Frieden.” In Den Frieden gewinnen. Zur Konsolidierung von Friedensprozessen in Nachkriegsgesellschaften, edited by Mir A. Ferdowsi and Volker Matthies, 42-69. Bonn: Dietz 2003.

"Stenohrama zasidannia RNBO Ukrainy u zviazku z pochatkom rosiiskoi ahresii v Krymu [Transcript of the National Security and Defense Council of Ukraine Meeting in the Aftermath of the Russian aggression in the Crimea]." Ukrainska Pravda, February 22, 2016. Accessed December 20, 2017. http://www.pravda.com.ua/articles/2016/o2/22/7099911/.

Syniak, Dmitrii. "My ostanovili krovotechenie v organizme armii — zamministra oborony Yurii Husev [We Have Stopped The Hemorrhage in the Army's Body-Yurii Husev, Deputy Minister of Defense]." Focus, November 10, 2015. Accessed December 20, 2017. https://focus. ua/country/339116/.

Tytysh, Halyna."Otladka mekhanizma. Aleksei Lipiridi o novoi gruppe po vyiavleniu problem na fronte, boitsakh i volonterakh [Setting up the Mechanism. Aleksei Lipiridi about the New Group on Checking the Problems at the Frontline, Soldiers and Volunteers]." Ukrainska Pravda, August 16, 2015. Accessed December 20, 2017. http://life.pravda.com.ua/ society/2015/o8/16/198654/.

"Volonter Nelli Stelmakh zvilnylasia z Minoborony [Volunteer Nelly Stelmakh Resigned from the Ministry of Defense]." Liga.net, November 6, 2015. Accessed December 20, 2017. http://news. liga.net/ua/news/politics/7039732-volonter_nell_stelmakh_zv_lnilasya_z_m_noboroni. htm.

Wright, Geoffrey. "Defense Reform and the Caucasus: Challenges of Institutional Reform during Unresolved Conflict." Mediterranean Quarterly 20.3 (2009): 13-39.

Kateryna Zarembo is Deputy Director at the New Europe Center (NEC), a think tank based in Kyiv, Ukraine. She co-teaches the "European Foreign and Security Policy" course under a 
joint Master's Programme of Jena University (Germany) and the National University of KyivMohyla Academy (Ukraine). Her areas of specialization are Ukraine's foreign policy, Ukraine's relations with the EU, Poland and Italy, EU CSDP missions in the Eastern neighbourhood, and Russia-Ukraine conflict. Kateryna holds a PhD in Political Science from the National Institute for Strategic Studies (Ukraine), an MA in European Studies from University College Dublin (Ireland) and an MA in English and Italian languages from Kyiv Taras Shevchenko University (Ukraine).

\section{Acknowledgements}

The author would like to thank Mikhail Minakov and Martin Brusis for their advice on methodology for this research; Natalia Shapovalova and Olga Burlyuk for their very valuable comments on the earlier versions of this article; Marta Puhach for her research assistance; and all the interviewees who shared with her their time and thoughts. Last but not least, the author is very grateful to Audrey Crummy for language editing of this paper. 